\title{
The Expression of Epistemic Uncertainty Through the Use of Distal Demonstratives in Russian and Chinese: A Cognitive Analysis of Corpus Data
}

\author{
Paola Bocale (Corresponding author) \\ Department of Human Sciences, Innovation and Territory (DISUIT), \\ Centre for Research on Minorities (CERM), University of Insubria \\ Via M. E. Bossi, 5, 22100 Como - Italy \\ Tel: 390-322-384-322Ｅ-mail: paola.bocale@ uninsubria.it
}

\begin{abstract}
Daniele Brigadoi Cologna
Department of Human Sciences, Innovation and Territory (DISUIT),

Centre for Research on Minorities (CERM), University of Insubria

Via M. E. Bossi, 5, 22100 Como - Italy
\end{abstract}

Received: February 11, 2020

Accepted: February 28, 2020

Published: March 8, 2020

doi:10.5296/ijl.v12i2.16438

URL: https://doi.org/10.5296/ijl.v12i2.16438

\begin{abstract}
In both Russian and Chinese, there are conditional connectives that appear in the apodosis of conditional sentences and are derived from non-proximal demonstratives. This work will concentrate on the Russian conditional connective to and the Chinese conditional connective nà, which share a similar development from distal demonstratives and exhibit similar syntactic, semantic and pragmatic properties. The analysis will take into account that both Russian to and Chinese nà are fundamentally deictic and have a motivated semantic content, which is closely related to the respective distal deictic demonstratives with the meaning that. The main question addressed in this work is how the semantics of distal demonstratives can account for their interaction with environments marked by epistemic uncertainty. In order to explain how the spatial relationship is transferred to the modal domain, the research will draw upon the theoretical framework of Deictic Space Theory, a cognitive linguistic theory which
\end{abstract}


grounds fundamental features of human language in spatial cognition. The analysis will show how the occurrence of distal deictics in constructions involving epistemic uncertainty can be explained as a metaphorical extension from the basic meanings of remoteness in space and time to remoteness in certainty.

Keywords: Russian demonstrative to, Chinese demonstrative nà, Epistemic modality, Distance, Conditionals

\section{Introduction}

In both Russian and Chinese distal demonstratives tend to be associated with non-factual, hypothetical or less certain propositions. This work will concentrate on the Russian conditional connective to and the Chinese conditional connective nà, which share a similar development from distal demonstratives and exhibit similar syntactic, semantic and pragmatic properties. Russian to and Chinese nà will not be treated as purely syntactic and independent of semantic content elements. Our analysis will take into account that both to and nà are fundamentally deictic and have a motivated semantic content, which is the same, or closely related to, the respective distal deictic demonstratives with the meaning that.

The main question addressed in this work is how the semantics of distal demonstratives can account for their interaction with environments marked by epistemic uncertainty. In order to explain the close connection between spatial distancing and epistemic interpretations, or how the spatial relationship is transferred to the modal domain, we will draw upon the concepts of epistemic modality, distance and deixis. After having presented the properties and functions of Russian and Chinese demonstrative systems, we will introduce Deictic Space Theory (Chilton, 2014), an essentially cognitive linguistic theory which grounds fundamental features of human language in spatial cognition, capturing spatial, temporal and modal conceptualizations through a three-dimensional abstract space in which axes represent distance from the speaker's deictic centre. The framework of Deictic Space Theory was chosen because the notion of epistemic uncertainty as the furthest point on modality axis intersecting with distance and time axes fits well with the analysis of Russian and Chinese non-proximal demonstratives, which combine a distal deictic value with temporal and epistemic meanings.

\section{Epistemic Modality}

Although there is consensus on considering modality as a semantic, rather than syntactic or morphological, category (only a semantically based account offers ground for cross-linguistic validity), definitions of modality differ widely across studies (see discussion in Narrog, 2005). Several approaches can be distinguished: 1) modality as the expression of the attitude of the speaker towards the proposition that the sentence expresses; 2) modality as the expression of realis vs. irrealis or factuality differences; 3) modality as the expression of possibility and necessity; 4) modality as the expression of subjectivity.

Two types of modality are identified: epistemic, which is "the category describing a speaker's opinion towards his propositional content" (Pietrandrea 2005: 7), and deontic, which is concerned with the necessity or possibility of acts performed by morally responsible agents 
(Lyons, 1977) (Note 1). The articulation of modality into epistemic and deontic is accounted for by the consideration that both share the features of subjectivity and non factuality, and by the fact that, crosslinguistically, epistemic and deontic meanings are often conveyed by the same forms (Palmer, 2001; Palmer, 2014). Epistemic modality may be considered a matter of degree or gradation, i.e. it involves a continuum going from absolute certainty via probability, neutral possibility, and, on the negative side, improbability to absolute certainty that the state of affairs is not real (Nuyts 2016: 38). Epistemic modality intermingles with the category of evidentiality in various degrees (Boye, 2012).

Epistemic modality expresses the speaker's subjective attitude towards the information being conveyed and is usually manifested on different levels of linguistic structure. In Russian and in Chinese epistemic modality can be expressed by a variety of different elements (for Russian see de Haan 2002; Plungian, 2005; Padučeva, 2016; for Chinese, Li, 2007; Huang and Shi, 2016; Meisterernst, 2016; Xiong and Meisterernst 2019). Grenoble (1998) underlines how modality should be considered as a discourse-level property, because the attitude of the speaker toward the proposition that it signals can only be understood within the larger context. Consequently, the grammatical category of epistemic modality should be detected not only at the morphological, but also at the discourse level.

\section{Distance}

The originally primarily spatial notion of distance has found wide application in linguistics in a variety of domains. Distance is a basic conceptual metaphor which extends or transfers to other cognitive domains fundamental bodily or spatial experience. The concept of temporal distance is considered, for example, as a metaphorical extension of a spatial concept (Fleischman, 1989). The understanding of distance as the gap or amount of space between two points has been, however, criticised for being too vague and, thus, not particularly useful for linguistic analysis. It is necessary to semantically ground the metaphor of distance and determine its manifestations in language (Sonnenhauser and Meermann, 2015).

A detailed examination of the different relationships of distance has been proposed in order to account for the complexity of its conceptualization in language (Zeman, 2015). Distance has emerged as a complex notion which incorporates both absolute and perceptional/perspectival distance relationships. Absolute distance is a two-dimensional possible link between two points on a ground, whereas perceptional/perspectival distance is three-dimensional since it includes a superordinate viewpoint. The linguistic conceptualization of distance is crucially linked to perceptional/perspectival features of viewpoint, because they trigger both directionality (i.e. the directed relationship between the specified entity and the reference point from which the entity is specified) and triangularity (i.e. the introduction of a third location). Conceptualizations of time and space rely on complex combinations of absolute and perceptional/perspectival distance relationships. The complexity of tense configurations, for example, can be interpreted as a result of a mix of absolute and perceptional distance in the sense of triangulation and of a combination of two different viewpoint configurations: the actual origo and a displaced point of perspective. Zeman believes that tense semantics "does 
not reflect a conceptualization of temporal distance in terms of absolute distance, but a relative concept linked to an observer's point of view" (Zeman, 2015: 20).

This work argues that distancing is closely related to the expression of epistemic uncertainty. The closeness between epistemic uncertainty and distancing arises from the fact that in asserting something not real, speakers metaphorically step away from the reality of a SoA. SoAs which do not occur in the 'here and now' of the speaker can be perceived as distanced from reality. As it will be explored later in this study, in addition to their basic function of marking spatial and temporal distance, in Russian and Chinese spatial distal markers also have extensions to constructions that involve non-reality. Their use in constructions marked by epistemic uncertainty can be interpreted as a metaphorical extension from the basic meaning of remoteness in space/time to remoteness in certainty: both spatial/temporal remoteness and uncertainty involve distance from the here-and-now, in one case distance in the domain of space/time, in the other distance in the domain of certainty.

\section{Deixis}

The traditional definition of deixis is that of a contextual-referential mechanism establishing a connection to a reference point. Bühler (1990 [1934]), calls this reference point the ego-hic-nunc origo (the I-here-now origin), Lyons (1977) the zero-point, and Fillmore (1997 [1971]) the deictic centre. Whatever the terminology, the personal origo is the actual speaker, the spatial origo is the speaker's location, and the temporal origo is the moment of the speech event. A speaker, in the moment of utterance, becomes the centre (origo) of a deictic field (or deictic space, Bühler's Zeigfeld), a system of personal, spatial, and temporal coordinates. Bühler identifies three modes of the referential act. The primary mode, from which all of the other deictic modes derive, is the demonstratio ad oculos (or aures), direct pointing by means of gestures or demonstratives to objects which are in the immediate surroundings. The second mode is anaphora, i.e. pointing by linguistic means to the verbal context. The third mode, deixis am phantasma (deixis in the imagination), i.e. pointing to non-present entities, is the transposition in the mental universe of the same process.

Following Bühler's investigation of the nature of the referent, traditionally three subcategories of deixis are identified: person, place, and time. Deixis of person encodes the participants in the speech event and is primarily found in the pronominal system. Deixis of space, which encodes the spatial locations in relation to the deictic centre, is divided in proximal deixis, i.e. forms that refer to locations close to the centre, and distal deixis, i.e. forms that refer to locations farther from the centre. Finally, deixis of time encodes certain points in time relative to a temporal reference point, usually the moment of utterance (Kragh and Lindschouw, 2013). Levinson (1983), following Lyons (1977) and Fillmore (1997 [1971]), adds two other deictic categories: 'social deixis', which encodes the social status of participants in the speech event, or aspects of the social relationship between them, and 'discourse deixis', which encodes reference to sections of the unfolding discourse itself.

Another dimension of deixis that is considered fundamental in some cognitive approaches is modal. Modal deixis refers to the fact that the "assertability of a proposition requires a judgment of relative factuality by the speaker, and this in turn necessitates a reference point 
against which to make the judgment. Modality thus exhibits all the classic symptoms of deixis" (Frawley 1992: 387). The expression of certainty and possibility is made with reference to a fixed reality point and can be regarded as deictic.

Unlike content words, deictic expressions are not directly concerned with meanings of some entities, but create a direct referential link between world and language (Diessel 2019b: 464).

Some approaches (see Jungbluth \& Da Milano, 2015) aim to overcome the limitations resulting from the traditional speaker- or distance-oriented view, which takes only the perspective of the speaker as origo, by grounding deixis in language use in dialogue.

"Language use is based in the Dualis, in the duality formed by at least two interlocutors, who together form the Origo based in the conversational dyad. The speaker speaks even to her- or himself as if speaking to another. The author writes her or his text expecting that it will be read by another. The other, the Alter indispensably complements the Ego. Without interlocutor she or he falls silent. The dialogue is not only the place where language use begins but an important part of human interaction" (Jungbluth \& Da Milano, 2015: 4).

\section{Demonstratives}

\subsection{Functions}

One of the most obvious employments of the basically spatial notion of distance is the analysis of demonstratives, which are linguistic tools primarily used for tying an utterance to its setting. Demonstratives have also other pragmatic functions. Diessel (1999) distinguishes the exophoric function, which is used to make reference to nonlinguistic entities in the surrounding speech situation, and the endophoric function, which is more anchored in the discourse itself and is divided in anaphoric, discourse-deictic and recognitional. Anaphoric demonstratives are coreferential with a noun phrase in the preceding discourse and help to keep track of prior discourse realities. Discourse demonstratives manage the flow of information by establishing a link between two propositions. Finally, recognitional demonstratives refer to entities that are neither present in the discourse situation, nor mentioned in previous discourse, but can be identified by speech participants on the basis of a shared knowledge. Exophoric demonstratives are the most prominent exponents of spatial deixis in language (Lander and Haegeman, 2018).

Demonstratives are often the source of grammatical function words, including articles, third-person pronouns, copular verbs, conjunctions and complementizers (Diessel 2019a: 167-169).

\subsection{Russian Demonstrative System}

Traditionally, Russian is described as a language with a binary system of demonstratives with the values proximal vs distal (Note 2). There are two demonstratives, which can be used adnominally and pronominally (Note 3): ètot, meaning this and tot, that. Ètot is described as the proximal member, and tot as the element marked for distance. However, recent research (Levinson, 2018) seems to indicate that ètot, which may be used just about everywhere, is 
actually unmarked for distance, but acquires its proximal meanings by pragmatic contrast to the marked distal tot. This finding would confirm previous observations suggesting that tot is less frequent than ètot, and it is usually accompanied by the demonstrative particle von, which reinforces its deictic and distal meaning (Berger, 1991). Tut/zdes' meaning here and tam, meaning there, are the Russian demonstrative adverbs. The neutralization of the proximal demonstrative would bring the Russian system of demonstratives closer to systems of other Slavic languages such as Polish.

\subsection{Chinese Demonstrative System}

The Chinese demonstrative system is divided between prototype demonstratives and demonstratives by sub-type (Wang, 1987a; Wang, 1987b). Prototype demonstratives consist of zhè meaning this and nà, that and their plural forms zhèxiē, these and nàxiē, those (xiē is a suffix marking plurality for the demonstratives). The other members of the demonstrative system are zhè-/nà-compounds such as zhèlı̆ or zhèr, meaning this place, here, nàlı̆ or nàr meaning that place, there, which express spatial location; zhèhuìr meaning now, at this moment, nàhuìr meaning then, at that moment, which express temporal location; zhèyàng, zhème, or zhèmezhe meaning this way, like this, so, such, nàyang, nàme, or nàmezhe meaning that way, like that, so, such, which express manner; zhème, zhèmege, zhèyàng, zhèdèng meaning this, like this, so, such, and nàme, nàmege, nàyàng, nàdèng meaning that, like that, so, such, which express degree.

Zhè, this and nà, that, if compared with these sub-type compounds, are prototypical because morphologically they are the stem morphs, and semantically it is their deictic ingredient and their proximity vs. non-proximity contrast that make it possible for the compounds to be classified as members of the demonstrative category.

The Chinese spatial demonstratives consist of the entity-referring demonstratives zhè, this and nà, that, which may be considered comparable, in a general sense, to the Russian entity-referring demonstratives ètot, this and tot, that, and the place-referring demonstratives zhèli/zhèr, here and nàli/nàr, there, which are comparable to the Russian place-referring demonstratives tut/zdes', here and tam, there.

\section{Deictic Space Theory}

Deictic Space Theory (Chilton, 2014) (Note 4) (further DST) is a cognitively motivated theory of linguistic description which is grounded in Mental Spaces Theory (Fauconnier, 1994) and in geometrical approaches to conceptualisation (Gärdenfors, 2000). Deixis is the overarching concept of the theory, which is built on the assumption that all utterances and their associated conceptualisation combine three conceptual scalar dimensions: attentional, or referential, distancing from the speaker, temporal distancing from the speaker and epistemic-modal distancing from the speaker. The three dimensions are represented geometrically as three intersecting axes: the distance (attentional) axis, the time axis and the modality axis. Each axis represents a scale of remoteness from the base space of the speaker, who is the zero point of now-here-real, the deictic centre. The relative distances on each axis correspond to the speaker's cognitive distance. 


\section{Mll Macrothink}

International Journal of Linguistics

ISSN 1948-5425

2020, Vol. 12, No. 2

The speaker and the axes constitute a frame of reference (i.e. a coordinate system which is specified by a centre point plus three directional axes), which is intrinsically deictic. The speaker's frame of reference is the reality space R, which is a cognitive version of Bühler's deictic field (Chilton, 2014: 48). DST posits a conceptual space consisting of three dimensions specific to the conceptualisation employed and induced by linguistic forms. This conceptual space is universal and language-independent. For every linguistic expression, the conceptual space contains several frames of reference, or copies of $\mathrm{R}$, which are virtual realities anchored at different deictic points in the speaker's R. DST can be considered consistent with a mental space approach because multiple deictic spaces can be set up relative to a speaker's R.

The distance axis points only in one direction (has no negative half line) and represents geometrically the difference between what is made grammatically salient and what is not in discourse. It has three fundamental points: proximal, medial and distal. These points are not spatial but represent different types of attentional distancing that are expressed in linguistic form. Proximal distance is described in terms of peripersonal space, a psychologically real region that is part of human consciousness. Proximal distance corresponds to the area denoted by proximal demonstratives, i.e. the deictic words, such as this, that refer to an entity close to the deictic centre, and that are in contrast to distal demonstratives, such as that, that refer to entities located in the extrapersonal space at some indeterminate distance from the speaker. DST maintains that proximal and distal determiners do not indicate precise measurements, but the entities to which they refer can be distinguished in terms of their relative distance from the deictic centre. Demonstratives' fundamental role is to establish joint attention in communication and direct attention to entities in the foreground and background of a deictically centred space.

Remote distance, again, is not defined spatially but in the sense of perceptual-conceptual accessibility and importance. Speakers, in conceptualising entities they are talking about (no matter whether they are physical and visually perceptible or not), can imagine them as conceptually closer and/or of greater attentional interest.

The time axis points in two opposite directions from time 0 , which is the time of the utterance: past $(-t)$ and future $(+t)$. The temporal dimension is framed in DST as relative distance from the now of the speaker, i.e. is conceptualised by analogy to spatial distance and direction. There are temporal points on the time axis that correspond to proximal, medial and distal. The proximal-medial-distal distinctions of the distance axis are thus projected also onto the time axis (and the modality axis). Peripersonal space is transposed onto the time axis: proximal temporal space matches spatial peripersonal space, i.e. it is peripersonal time. Persipersonal time is made of memory of the recent past (memories of actions just performed) and anticipation and planning for the immediate future (intentions for one's next actions). DST claims that the time axis is not the conventional time arrow because it can be directed according to the speaker's viewpoint. In some languages, such as English, the directions correspond to a front-back orientation, whereas other languages may have other orientations, such as up-down. 


\section{Macrothink}

International Journal of Linguistics

ISSN 1948-5425

2020, Vol. 12, No. 2

The modality axis represents epistemic modality and, as the distance axis, points only in one direction from the deictic centre. Its function is to reflect what is a universal characteristic of all utterances, namely the fact that speakers can epistemically distance their contents from absolute truth. So the modality axis is posited in order to account for the linguistic encoding of reality assessments. Modality can be modelled in spatial terms by conceptualising states of affairs as being positioned along an epistemic scale with the polar opposites 'certainly true' and 'certainly not true', or realis and irrealis. The fact that modal elements can be graded (for example the English modal adjectives necessary, probable, possible, uncertain, improbable, impossible and so on) confirms that there are degrees of assessment of certainty.

The epistemic scale is

metaphorically spatial in the sense that realis representations are positioned at S's known reality; what S considers irrealis is 'distant' from S, or 'remote', 'located' at degrees of distance, with a limiting point that is counter to fact, i.e. 'opposite' to S's known reality. It is the conceptual elements of direction and distance that justify epistemic modality being characterised as deictic (Chilton, 2014: 38).

In DST realis and irrealis are conceived of as the limiting points of the epistemic scale. The terms are not used to denote grammatical categories but cognitive states, with which linguistic expressions may be associated: a realis representation is a cognitive state in which speaking subjects take some SoA to be real or consistent with their encyclopaedic knowledge, whereas an irrealis representation is one in which speakers consider a SoA as being somehow removed from realis cognition.

DST's geometrical modelization of linguistic meaning in a cognitive embodied framework provides consistent and convincing support for the hypothesis that distal deictics play a role in conveying epistemic uncertainty. The three-dimensional deictic space, consisting of the intersecting axes of attitudinal distance, time and modality, helps us to visualize the interrelatedness and interdependence of epistemic modality, distance and deixis.

\section{Data}

For Russian, data comes from the multimedia Russian speech corpus MURCO (Grishina, 2009), which is a subcorpus aimed for studies of conversational speech of the Russian National Corpus (http:// ruscorpora.ru). From the MURCO corpus, only transcripts of spoken Russian aligned with corresponding video clips were used for this study, and not the transcriptions of Russian movies, which are also available on this corpus.

For Chinese, the research is based on data from the the PolyU Corpus of Spoken Chinese (http://asianlang.engl.polyu.edu.hk), an example corpus which formed the basis for the design of Huang and Shi (2016) reference grammar. The PolyU Corpus of Spoken Chinese consists of 28 transcripts of audio-recordings of conversational exchanges in Chinese concerning a range of subjects, including travel talk and life experiences (Note 5).

\section{Russian and Chinese Distal Demonstratives in Conditional Sentences}

In both Russian and Chinese, there are conditional connectives that appear in the apodosis of 


\section{Macrothink}

conditional sentences and are derived from non-proximal demonstratives with the meaning that.

\subsection{The Russian Conditional Connective to}

The Russian connective to, which comes from the singular neuter demonstrative pronoun to 'that' (Preobraženskaja, 1983), combines with a range of subordinating conjunctions, including esli 'if', raz 'since', kogda 'when', poka 'while', poskol'ku 'since' and tak kak 'since'. Russian conditional constructions are marked in the antecedent by the subordinator esli (Note 6) 'if', usually, but not necessarily, followed in hypothetical conditionals by the particle by. By is then repeated in the consequent where it generally appears immediately after the 1-participle/infinitive, or immediately before it (Gurevich, 2010) (Note 7).

In conditional constructions, to is strongly correlated with esli and cannot occur alone as the only linking conjunction (see example 1).

Example 1. (Note 8)

$\begin{array}{lllll}\text { esli } & \text { by } & u & \text { nego } & \text { samogo } \\ \text { if } & \text { BY } & \text { by } & \text { him } & \text { himself } \\ \text { takogo } & \text { pečal'nogo } & \text { opyta } & \text { ne } & \text { bylo } \\ \text { such } & \text { sad } & \text { experience } & \text { NEG } & \text { was } \\ \text { to } & \text { on } & \text { nikogda } & \text { by } & \text { ne } \\ \text { TO } & \text { he } & \text { never } & \text { BY } & \text { NEG }\end{array}$

podozreval

suspected

[MURCO]

if he himself hadn't had such sad experience, TO he would never have suspected

A major question is what motivates or licenses the use of to in Russian conditional constructions, where its presence is considered by reference grammars as optional (Švedova, 1980). In most cases the connective to may be present or absent in the apodosis when the protasis is introduced by esli, without changes to the overall sentence meaning:

Example 2

$\begin{array}{lllll}\text { esli } & \text { by } & s & \text { nami } & \text { postojanno } \\ \text { if } & \text { BY } & \text { with } & \text { us } & \text { constantly } \\ \text { poechal } & \text { by } & \text { Oleg } & \text { ja } & \text { dumaju } \\ \text { went } & \text { BY } & \text { Oleg } & \text { I } & \text { think } \\ \text { my } & \text { by } & s & \text { toboj } & \text { otdochnuli } \\ \text { we } & \text { BY } & \text { with } & \text { you } & \text { had.a.holiday } \\ \text { by } & \text { velikolepno } & & & \\ \text { BY } & \text { magnificently } & & & \end{array}$

[MURCO]

If Oleg constantly came with us I think we would have wonderful vacations 


\section{Macrothink}

Podlesskaya (1997) suggests that the use of to in the apodosis marks the topicality of the protasis, although morphosyntactically it appears outside it; if the protasis is focal, to is forbidden. Therefore, according to this analyst, to cannot be used when the protasis is marked by focus particle (such as tol'ko 'only' in tol'ko esli 'only if', example 3, or if the protasis is parenthetical (i.e. it contains stance markers, epistemic adverbial phrases such as esli ja ne ošibajus' 'If I am not mistaken', see example 4, so not topical. Conversely, it cannot be omitted when the topical status of the protasis is marked by special devices such as frame constructions, which are devices used to introduce a thematically important referent (such as čto kasaetsja menja 'according to me', see example 5. Pekelis (2016) confirms these restrictions in the use of to, adding that to serves to contrastively emphasize the implicative relation expressed by the conjunction it combines with.

Example 3

$\begin{array}{lllll}\text { tol'ko } & \text { esli } & \text { operaciju } & \text { sdelat' } & \text { nemedlenno } \\ \text { only } & \text { if } & \text { operation } & \text { do } & \text { immediately } \\ * \text { to/0 } & \text { ostanetsja } & \text { ešče } & \text { kakaja-to } & \\ & \text { remain } & \text { still } & \text { some } & \\ \text { nadežda } & \text { ego } & \text { spasti } & & \\ \text { hope } & \text { him } & \text { save } & & \end{array}$

[Podlesskaya 1997: 137]

Only if [they] perform an operation immediately, will there remain some hope to save him

Example 4

$\begin{array}{lllll}\text { Esli } & j a & n e & \text { ošibajus' } & * \text { to/0 } \\ \text { if } & \mathrm{I} & \mathrm{NEG} & \text { be mistaken } & \\ \text { my } & \text { sejčas } & \text { dolžny } & \text { povernut } & \text { napravo } \\ \text { we } & \text { now } & \text { must } & \text { turn } & \text { to-the-right }\end{array}$

[Podlesskaya 1997: 138]

If I am not mistaken, we must turn to the right

Example 5

$\begin{array}{llll}\text { Čto } & \text { kasaetsja } & \text { menja } & * \text { to/0 } \\ \text { what } & \text { concerns } & \text { me } & \\ n a & \text { konferenciju } & \text { ne } & \text { poedu } \\ \text { to } & \text { conference } & \text { NEG } & \text { will.go }\end{array}$

[Podlesskaya 1997: 138]

Speaking about myself, I am not going to the conference

Apart from the truly conditional esli, all the other subordinating conjunctions to combines with - raz 'since', kogda 'when', poka 'while', poskol'ku 'since, given that', tak kak 'since' - are close to conditional connectors in that they express a causal meaning through a conditional one, see examples $6-10$ below. 
Example 6

$\begin{array}{lllll}a & j a & \text { tože } & k s t a t i & \text { chotela } \\ \text { and } & \text { I } & \text { also } & \text { by.the.way } & \text { wanted } \\ \text { tuda } & \text { segodnja } & \text { schodit' } & n u & \text { raz } \\ \text { there } & \text { today } & \text { go } & \text { well } & \text { since } \\ \text { tam } & \text { narodu } & \text { mnogo } & \text { to } & \text { ne } \\ \text { there } & \text { people } & \text { a.lot } & \text { TO } & \text { NEG } \\ \text { pojdu } & & & & \\ \text { will.go } & & & & \end{array}$

[MURCO]

And I, too, by the way, wanted to go there today. Well, since there are a lot of people, TO I won't go

Example 7

\begin{tabular}{|c|c|c|c|c|}
\hline$T y$ & $\check{z}$ & menja & znaeš' & ja \\
\hline you & EMPH & me & know & I \\
\hline voobšče & ljublju & detskie & $k n i z ̌ k i$ & detskie \\
\hline generally & love & children's & books & children's \\
\hline fil'my & $a$ & kogda & èto & ešče \\
\hline films & and & when & this & more \\
\hline$s$ & dušoj & sdelano & to & voobšče \\
\hline with & soul & done & TO & generally \\
\hline gotova & pljasat' & ot & radosti & \\
\hline ready & dance & from & joy & \\
\hline
\end{tabular}

[MURCO]

You know me I generally like children's books / children's films .... And when it's done with the heart TO I'm generally ready to dance with joy

Example 8

$\begin{array}{lllll}\text { no } & \text { nulevoj } & \text { uroven' } & \text { on } & \text { konečno } \\ \text { but } & \text { zero } & \text { level } & \text { it } & \text { of.course } \\ \text { neobchodim } & \text { potomu čto } & \text { poka } & \text { ego } & \text { net } \\ \text { necessary } & \text { because } & \text { while } & \text { it } & \text { NEG } \\ \text { to } & \text { nikakoj } & \text { ša } & \text { vy } & \text { ne } \\ \text { TO } & \text { any } & \text { step } & \text { you } & \text { NEG } \\ \text { sdelaete } & \text { skorej } & \text { vsego } & & \\ \text { will.do } & \text { more.likely } & \text { of.all } & & \\ \text { [MURCO] } & & & & \end{array}$

But the zero level it's, of course, necessary, because until it's not there TO you will not take any step, most likely 


\section{Ml Macrothink}

Example 9

$\begin{array}{lllll}a & j a & \text { govorju } & \text { poskol'ku } & \text { ja } \\ \text { and } & \text { I } & \text { say } & \text { since } & \text { I } \\ n e & \text { slyšala } & \text { poka } & \text { takoj } & \text { zajavki } \\ \text { NEG } & \text { heard } & \text { so.far } & \text { such } & \text { request } \\ s & \text { drugoj } & \text { storony } & \text { to } & \text { ja } \\ \text { from } & \text { other } & \text { side } & \text { TO } & \text { I } \\ n e & \text { choču } & & \\ \text { NEG } & \text { want } & & \\ \text { [MURCO] } & & & \\ \text { and I say since I have not heard such a request from the other side TO I don't want to }\end{array}$

Example 10

$\begin{array}{lllll}\text { otec } & \text { tak kak } & \text { on } & \text { byl } & \text { člen } \\ \text { father } & \text { since } & \text { he } & \text { was } & \text { member } \\ \text { sem'i } & \text { vraga } & \text { naroda } & \text { to } & \text { on } \\ \text { family } & \text { enemy } & \text { people } & \text { TO } & \text { he } \\ \text { nikuda } & \text { postupit' } & \text { učit'sja } & \text { ne } & \text { mog } \\ \text { anywhere } & \text { enter } & \text { to.study } & \text { NEG } & \text { could }\end{array}$

[MURCO]

My father since he was a family member of an enemy of the people TO he couldn't go anywhere to study

Conjunctions which are exclusively causal and not conditional, such as potomu čto or ottogo čto, both meaning because, cannot combine with to.

We argue that the combinability of to, and its restrictions, are related to its semantics, and that it is possible to provide a motivated account of the use of this connective by taking into account its spatial deictic meaning, which is the same, or closely related to, the distal demonstrative pronoun to. The distal semantics of to makes it a distancing device, which points towards a space which is distal from the space of the antecedent clause. Conditional sentences give mental representations of degrees of irreality, that lie, in DST account, somewhere along the m-axis (Chilton 2014: 159). The Russian connective to points deictically to a particular mental space, and situates the state of affairs described in the apodosis in that mental space, which is identified to the exclusion of other possible spaces. The inclusion of to in the apodosis invites the inference that its content does not hold in other, alternative spaces.

A confirmation of the contrasting fuction of to comes from its use in the negative conditional connectives $a$ to and $a$ ne to, which can be roughly translated as otherwise:

Example 11

$\begin{array}{lllll}\text { pišite } & \text { požalujsta } & \text { čerez } & \text { stročku } & a \\ \text { write } & \text { please } & \text { through } & \text { line } & \text { and } \\ \text { to } & \text { očen' } & \text { trudno } & \text { razobrat' } & \text { čto }\end{array}$


TO very difficult to.understand what

napisano

written

[MURCO]

Write, please, through a line, and TO it's very difficult to understand what is written

Example 12

$\begin{array}{lllll}\text { derži } & \text { brevno } & a & \text { ne } & \text { to } \\ \text { hold } & \log & \text { and } & \text { NEG } & \text { TO } \\ \text { ono } & \text { lomaet } & \text { našu } & \text { plotinu } & \\ \text { it } & \text { breaks } & \text { our } & \text { dam } & \end{array}$

[MURCO]

Hold the log and NEG TO it will break our dam

The inclusion of to in negative conditional connectives also reveals the sequentializing function of this connective, since $a$ to and $a$ ne to, conjoin sentences whose temporal relation is sequential rather than cotemporal, because they code implicative relations between negative prepositional extractions from the protases and their apodoses, presenting these relations as reasons for the protases.

If we now look back at corpus examples of to in conditional sentences, it becomes apparent that its use is particularly common in sentences which involve inferential reasoning such as representing alternative situations (example 13), mental simulation (example 14), causal/sequential thinking (example 15), and probabilistic predictions (example 16):

Example 13

\begin{tabular}{|c|c|c|c|c|}
\hline potomu čto & znaete & vot & predel'no & otkrovenno \\
\hline because & you.know & VOT & to.the.limit & openly \\
\hline Vam & govorju & esli & by & ja \\
\hline you & say & if & BY & I \\
\hline bojalsja & ostat'sja & bez & raboty & ili \\
\hline was.afraid & remain & without & work & or \\
\hline strašno & chotel & by & prodolžit' & rabotu \\
\hline terribly & wanted & BY & continue & work \\
\hline$v$ & dol'žnosti & Prezidenta & to & ja \\
\hline in & position & president & TO & I \\
\hline by & ne & postupil & tak & kak \\
\hline BY & NEG & acted & so & as \\
\hline ja & postupil & & & \\
\hline I & acted & & & \\
\hline
\end{tabular}

[MURCO]

Because you know I am telling you very frankly if I was afraid to remain without work or would really like to continue working as President I would not have acted the way I acted' 


\section{Ml Macrothink}

Example 14

$\begin{array}{lllll}\text { esli } & \text { predstavit' } & \text { na } & \text { ploskosti } & \text { vot } \\ \text { if } & \text { imagine } & \text { on } & \text { plane } & \text { VOT } \\ \text { zdes' } & \text { levye } & z d e s^{\prime} & \text { centr } & \text { zdes' } \\ \text { here } & \text { left } & \text { here } & \text { centre } & \text { here } \\ \text { pravye } & \text { to } & u & \text { nas } & \text { vertikal' } \\ \text { right } & \text { TO } & \text { by } & \text { us } & \text { vertical } \\ \text { kak } & \text { rostok } & \text { iz-pod } & \text { asfal'ta } & \text { tak } \\ \text { like } & \text { sprout } & \text { from-under } & \text { asphalt } & \text { so } \\ \text { rastet } & \text { Partija } & \text { žisni } & & \\ \text { grows } & \text { party } & \text { of.life } & & \\ \text { [MURCO] } & & & & \end{array}$

If you imagine on a plane here are the left here is the centre here is the right TO we have a vertical like a sprout from under the asphalt grows the Party of Life

Example 15

$\begin{array}{lllll}\text { no } & \text { esli } & \text { vse } & \text { pravil'no } & \text { sdelat' } \\ \text { but } & \text { if } & \text { everything } & \text { right } & \text { do } \\ i & v & \text { pogodu } & \text { popast' } & \text { to } \\ \text { and } & \text { in } & \text { weather } & \text { get } & \text { TO } \\ \text { nadežno } & \text { polučaetsja } & \text { na } & \text { ètoj } & \text { gore } \\ \text { reliably } & \text { get.REFL } & \text { on } & \text { this } & \text { mountain }\end{array}$

[MURCO]

But if you do everything right and get the right weather TO you get it right on this mountain

Example 16

$\begin{array}{lllll}\begin{array}{l}\text { doma } \\ \text { at.home }\end{array} & \text { esli } & \text { mat' } & \text { govorit } & \text { 'kupila' } \\ a & \text { if } & \text { mother } & \text { say } & \text { bought } \\ \text { and } & \text { ne } & \text { 'vzjala' } & \text { to } & \text { verojatnost' } \\ \text { togo } & \text { NEG } & \text { took } & \text { TO } & \text { probability } \\ \text { of.that } & \text { čto } & i & \text { deti } & \text { budut } \\ \text { govorit' } & \text { that } & \text { and } & \text { children } & \text { will } \\ \text { say } & \text { verno } & \text { naibol'saja } & i & \text { naoborot } \\ \text { correctly } & \text { greatest } & \text { and } & \text { vice versa }\end{array}$

[MURCO]

At home if the mother says 'bought' and not 'took' TO the probability that the children will speak correctly is the greatest and vice versa

In all of the above examples (13 - 16), to could be translated in English as then, a temporal conjunction which signals a sequence of events, in which the occurrence of the apodosis follows conditionally on the occurrence of the event in the protasis (Dancygier, 1999). The Russian connective to has thus distinct, sequentializing temporal functions. 


\section{Macrothink}

International Journal of Linguistics

ISSN 1948-5425

2020, Vol. 12, No. 2

Our analysis of to as a sequentalizing device also explains why its use is not possible in conditionals where the antecedents are parentheticals and frame constructions, which are not sequentially related to their consequents.

\subsection{The Chinese Conditional Connective nà}

Like Russian to, the Chinese demonstrative nà meaning that has developed connective functions in a variety of grammatical contexts. In this work we will analyse its occurrence in conditional sentences (Wang, 2015). In Chinese, hypothetical or counterfactual conditional sentences can be introduced in the protasis by the conjunctions rúguó or yàoshi meaning if (Sun, 2006).

When nà appears initially in the apodosis of overtly marked conditional sentences is a clitic which receives no stress. Similarly to Russian to, it's occurrence is optional, i.e. nà may be present or absent in the apodosis when the protasis is introduced by conditional markers, without changes to the overall sentence meaning, compare examples 17-19 with nà, and examples 20-23 where nà is absent.

In order to illustrate the use of nà in contemporary spoken Mandarin, a selection of examples from the PolyU Corpus of Spoken Chinese (Mandarin) will be given. Interestingly, this corpus only features one occurrence of yàoshi in conjunction with nà (example 17), out of a total of 30 occurrences of yàoshi in hypothetical or conditional sentences. Given that the use of yàoshi is generally considered more common in spoken Mandarin, the utter prevalence of hypothetical or conditional sentences introduced by rúguǒ (with or without nà) in this corpus seems to point to an ongoing shift of this rather formal conditional marker from the literary to the spoken register.

\section{Example 17}

$\begin{array}{lllll}\text { Yàoshi } & \text { lìngdăo } & \text { pīpíng } & \text { wǒ } & \text { wǒ } \\ \text { If } & \text { leadership } & \text { criticize } & \text { I } & \text { I } \\ \text { jiù } & \text { fănjí } & \text { dehuà, } & \text { nà } & \text { zăo } \\ \text { JIÙ (Note 9) } & \text { fight back } & \text { DEHUÀ } & \text { NÀ } & \text { early } \\ \text { hùn } & \text { bù } & \text { xiàqùle } & & \\ \text { muddle along } & \text { NEG } & \text { carry on } & & \\ \text { [PolyU_Man_ER_18.txt] Mandarin/39 } & & \end{array}$

If I fought back when the leadership criticized me, NÀ I would not have been able to muddle along from the early beginning

When yàoshi is used without nà, the apodosis may sound more emphatic, even abrupt, and often triggers the use of jiù in the consequent. However, in the PolyU corpus yàoshi is frequently used to express a supposition, even a counterfactual one, without necessarily conveying abruptness, but rather an insistent request for affirmation or negation. 


\section{Macrothink}

Example 18

$\begin{array}{lllll}\text { Nín } & \text { juéde } & \text { yàoshi } & \text { qù } & \text { lǘxíng } \\ \text { You (formal) } & \text { feel } & \text { if } & \text { go } & \text { travel } \\ \text { dehuà, } & \text { huì } & \text { juéde } & \text { xiăng } & \text { qù } \\ \text { DEHUÀ, } & \text { would } & \text { feel } & \text { want } & \text { go } \\ \text { Xiānggăng } & \text { kànkan } & \text { ma? } & & \\ \text { Hong Kong } & \text { take a look } & \text { MA? } & & \\ \text { [PolyU_Man_TP_8.txt] Mandarin/193 } & \\ \text { Do you feel that if you were to go on a trip, you think you would want to go to Hong } \\ \text { Kong and take a look? }\end{array}$

In the PolyU corpus, hypothetical or conditional sentences with rúguó occur much more frequently than those with yàoshi. Most of them in the apodosis do not feature nà, which appears only in 20 instances out of a total 155 occurrences of rúguó (13\%). A common pattern is that of rúguó in the antecedent in connection with yībān 'generally' in the consequent, in order to convey the action which is performed or the attitude which is assumed under the condition or hypothesis expressed in the protasis (example 19). In most cases the apodosis does not contain any connective (example 20).

Example 19

\begin{tabular}{|c|c|c|c|c|}
\hline$N g$ & nà & rúguǒ & yǒurén & bù \\
\hline $\mathrm{Hm}$, & so & if & someone & NEG \\
\hline xiāngxìn & $n \check{i}$ & $y \underline{\underline{z}} b \bar{a} n$ & $n \check{~}$ & huì \\
\hline believe & you, & generally & you & would \\
\hline уо̆и & shénmeyàng & $d e$ & gănshòu? & \\
\hline have & what kind & $\mathrm{DE}$ & feeling & \\
\hline
\end{tabular}

Example 20

$\begin{array}{lllll}\text { Tāa } & \text { zhuān } & d \bar{o} u, & \text { dōu } & \text { yào } \\ \text { Its } & \text { bricks } & \text { all, } & \text { all } & \text { must } \\ \text { biāo } & \text { chūlai, } & \text { jiù } & \text { shì } & \text { nă } \\ \text { sign } & \text { come out/show } & \text { JIÙ } & \text { is } & \text { which } \\ \text { kuài } & \text { rúguó } & \text { chì } & \text { wèntí, } & \text { tā } \\ \text { piece }(m . w .) & \text { if } & \text { cause } & \text { problem, } & \text { he } \\ \text { qù } & \text { zhăo } & n a ̀ & \text { rén } & \\ \text { go } & \text { to look for } & \text { that } & \text { person } & \end{array}$

[PolyU_Man_TP_18.txt] Mandarin/45

Its bricks are all, they all must be signed, that is, any brick, if it causes a problem, (then) one can go look for the man (who made it) (Note 10)

When nà does occur in the apodosis after a protasis introduced by rúguǒ, its function seems to correspond to what $\mathrm{Wu}$ (2004: 105-106) suggested for its employment in conjunction with 


\section{Al Macrothink}

International Journal of Linguistics

ISSN 1948-5425

2020, Vol. 12, No. 2

hypothetical or conditional markers, namely that nà in the consequent refers backwards to the condition expressed in the antecedent and signals that the state of affairs in the apodosis will necessarily arise if the condition in the protasis is fulfilled.

Example 21

$\begin{array}{lllll}\text { Jiù... } & \text { rúguǒ } & \text { yǒurén } & \text { qiăngpò, } & \text { nà } \\ \text { JIÙ... } & \text { if } & \text { someone } & \text { force } & \text { NÀ } \\ \text { wǒ } & \text { huì } & y a & & \\ \text { I } & \text { would } & \text { YA } & & \end{array}$

[PolyU_Man_CR_20.txt] Mandarin/29

Well... if someone were to force me, NÀ I would, sure enough (Note 11)

Example 22

\begin{tabular}{|c|c|c|c|c|}
\hline Dànshì & rúguǒ & shuō & shì, & jiù \\
\hline But & if & say & is, & JIÙ \\
\hline shì & bijjiào & qīnmi & $d e$ & bǐrú \\
\hline is & relatively & intimate & $\mathrm{DE}$, & for instance \\
\hline shuō & péngyou, & qīnrén & bù & xiāngxìn \\
\hline say & friend & relative & NEG & believe \\
\hline wó, & nà & huì & bǔjiào & shēngqì \\
\hline $\mathrm{I} / \mathrm{me}$ & NÀ & would & relatively & angry \\
\hline$b a$, & huòzhě & shuō & huì & jíyú \\
\hline BA, & or & say & would & anxious \\
\hline$q u ̀ ~$ & jiěshì & $\bar{a}$. & & \\
\hline go & explain & $\overline{\mathrm{A}}$ & & \\
\hline
\end{tabular}

But if, let's say, it were someone relatively close, say, for example, a friend, a relative, who would not believe me, NÀ I would be pretty upset, you know, or I would be anxious to get an explanation

Through an inversion of the canonical protasis-apodosis order of conditional sentences, sometimes the apodosis introduced by nà can be anticipated, while the protasis introduced by the conditional marker rúguó is moved forward, towards the end of the sentence. In such cases it is also common a co-occurrence with jiù or yě in the consequent to form a hypothetical conditional sentence. The following examples 23, 24 provide, respectively, illustrations of both a canonical rúguó..., nà (jiù) construction and of a non-canonical one (nà..., rúguó...), with the apodosis moved to the front. 
Example 23

\begin{tabular}{|c|c|c|c|c|}
\hline Duì, & jiùshishuō, & nà & jiù & shì \\
\hline Precisely, & I mean, & NÀ & JIÙ & is \\
\hline "shizài & duibuqǐ", & kěnéng & huì & zhème \\
\hline "really & sorry", & probably & would & thus \\
\hline shuō, & rúguǒ & shuō & $n \check{~}$ & quèshí \\
\hline speak, & if & say & you & really \\
\hline duì & biéren & zàochéng & hěn & $d \grave{a}$ \\
\hline to & others & cause & very & big \\
\hline máfan & dehuà, & huòzhě & shuō & $z \grave{a ̀ i}$ \\
\hline nuisance & DEHUÀ, & or & say & at \\
\hline gōngzuò & shàng & 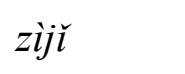 & yǒu & hĕn \\
\hline work & on & oneself & have & very \\
\hline dà & shīwù, & nà & $z h \grave{\imath}$ & néng \\
\hline big & mistake, & NÀ & only & can \\
\hline shuō & shízài & duibuqǔ, & ránhòu & jiù \\
\hline say & really & sorry, & afterwards & JIÙ \\
\hline zěnme & míbǔ, & huòzhě & shuō & péi \\
\hline how & make good & or & say & reimburse \\
\hline rénjiā & qián & huòzhě & zěnmeyàng & $d e$ \\
\hline someone & money & or & how & $\mathrm{DE}$ \\
\hline huòzhě & shì & jiābèi & nǔlì & \\
\hline or & is & increase & effort & \\
\hline
\end{tabular}

[PolyU_Man_ER_18.txt] Mandarin/59

Precisely, I mean, in that case "(I am) really sorry", (that's what I would) probably say, if say you really caused someone a big nuisance, or say (you) made a huge mistake on the job, NÀ (you) can only say (that you are) really sorry, afterwards (you work out) how you are going to make up for it, or say you reimburse them money or something like that, or you make a greater effort (in your work) 


\section{Mll Macrothink}

Example 24

\begin{tabular}{|c|c|c|c|c|}
\hline$N a ̀$ & zǒngyào & jiù & $b \check{a}$ & jùtǐ \\
\hline NÀ & always & JIÙ & $\mathrm{BĂ}$ & concrete \\
\hline de & cuòsh̄̄ & jiăng & chūlai & $b a$ \\
\hline $\mathrm{DE}$ & measures & explain & (dir. comp.) & $\mathrm{BA}$, \\
\hline jiù & kěnding & bú & shì & shuō \\
\hline JIÙ & surely & NEG & is & say \\
\hline$j \check{l}$ & ge & yŭqicí & jiù & néng \\
\hline a few & $\mathrm{GE}(m . w)$. & kind words & JIÙ & can \\
\hline jiějué & $d e$ & rúguó & hěn & yánzhò \\
\hline solve & $\mathrm{DE}$ & if & very & important \\
\hline de & cuòwù & dehuà. & & \\
\hline
\end{tabular}

DE mistake DEHUÀ

[PolyU_Man_ER_18.txt] Mandarin/59

NÀ (you) always have to spell out the concrete measures, (you) surely cannot just say a few kind words and be able to resolve (the situation), if (it's) a big mistake

In colloquial Chinese nà can also occur sentence initially as a chaining device to link that sentence to the preceding stretch of discourse. In this case its function is sequential and inferential ('given A, infer B'), i.e. it can express a temporal connection between two events and imply a cause and effect relationship between them. The meaning of this nà, which can only be inferred from the context, is close to that of the sequential markers therefore, then, that's why, for that reason, because of that. It can also carry a meaning akin to in that case, if that's the case, conveying a conditional or hypothetical nuance, as pointed out in $\mathrm{Wu}$ (2004: 107). The following example illustrates an occurrence of the connective nà at the opening of a sentence which it links to the preceding discourse. Its use in the protasis could be compared to that of a spatial marker. The antecedent with nà is almost immediately followed by a consequent with jiù.

(The context of example 25 is as follows: the informant is discussing whether to choose a Chinese style or a Western style wedding. She has just made a few observations on the Chinese style wedding, when she is asked the question below).

Example 25

\begin{tabular}{|c|c|c|c|c|}
\hline$N a ̀$ & $n \check{\imath}$ & jiù & b̌rrú & shuō \\
\hline NÀ & you & JIÙ & for instance & say \\
\hline yào & hé & $x \bar{i} s h i$ & de & xuăn \\
\hline must/have to & with & western style & $\mathrm{DE}$ & choose \\
\hline$y \bar{\imath}$ & $g e$ & ne? & & \\
\hline one & $\mathrm{GE}(m . w)$. & NE? & & \\
\hline
\end{tabular}

(And) NÀ you for instance had to choose a western one?

[And if you, for instance, had to choose a western one?] 
A similar use of nà can also be observed with more formal conditional markers, such as jiărú, in constructions which rarely enter the spoken register, but could arguably be understood as "softer" variants of more literary conditional constructions. Jiărú is often employed together with nàme, in this case suggesting "manner" instead of "place", yet to similar effect. As there were no occurrences of jiărú in the PolyU corpus, the example (26) is excerpted from the Peking University Center for Chinese Linguistics corpus (CCL) (Note 12).

Example 26

\begin{tabular}{|c|c|c|c|c|}
\hline Jiărú & $n \check{\imath}$ & bù & dǒngde & luógèsī, \\
\hline If & you & $\mathrm{NEG}$ & understand & $\log o s$ \\
\hline bù & zhīdào & xīfāngrén & kăolùu & shénme, \\
\hline NEG & understand & Westerners & reason & what \\
\hline nà & $n \check{\imath}$ & jiù & gēnběn & bù \\
\hline NÀ & you & JIÙ & radically & NEG \\
\hline dǒng & xīfāng & & & \\
\hline understand & West & & & \\
\hline
\end{tabular}

[CCLl当代ICWAC\APM0061.txt/21.1]

If you do not understand logos, you do not understand what Westerners reason about, NÀ you cannot understand the West at all

We argue that, similarly to what happens with Russian to, the use of nà is related to its semantics, and that the factors that govern and motivate its use are linked to its spatial deictic meaning, which is the same, or closely related to, the distal demonstrative pronoun nà. Nà points towards a space which is different and non-proximal in relation to the space of the antecedent clause; it iconically distances the apodosis from the protasis, or a sentence from preceding discourse, when it is used in sentence-opening position in simple sentences with an implied conditional/causal meaning. More importantly, nà distances the clause it opens from epistemic certainty and commitment. Spatial non-proximity becomes epistemic non-proximity, i.e. distance from reality. Although the presence of nà is syntactically optional, pragmatically it is significant (clauses without nà may sound too emphatic, even a bit harsh), and motivated by its semantics.

\section{Discussion}

This research explored one of the environments highly correlated with the expression of epistemic uncertainty where Russian and Chinese distal demonstratives occur. In conjunction with our investigation, the question we sought to answer was why distal deictics appear in contexts marked by conditionality, non-factuality and hypotheticality. We will now draw together the empirical and theoretical strands of the study and reflect on what the insights imply for the debate on epistemic modality.

Central to the issue discussed in this work is the observation that the use of distal demonstratives in environments of epistemic uncertainty is motivated by their central meaning. The basic semantics of distal deictics corresponds to whatever is distal or invisible to the speaker and to his scenario. However, in Russian and Chinese distal deictis not only 
express semantic distance (temporal or geographical) with respect to a proposition, but also 'epistemic distance', which Plungian (2010: 47) describes as a modality in which "the speakers are released from the responsibility for the truth of the utterance". Epistemic distance is the feature triggering the expansion of uses from one conceptual domain to another. In the case of Russian and Chinese distal demonstratives, the concept of epistemic distance is mapped on distance in physical terms, i.e. on their literal meaning. The original spatial distal meaning of the source form has shifted to epistemic meanings associated with the speaker's attitude toward the reality/factuality of the event.

The geometrical modelization of the three-dimensional deictic space proposed by DST, a cognitively motivated theory of linguistic description, convincingly provides a visual representation of this process. The three dimensions of DST - the d (distance), $t$ (time) and $\mathrm{m}$ (modality) axes - stem from the deictic centre and are scales on which distance is represented in the direction pointing away from the speaker. From the speaker's point of view, this three-axis system constitutes the reality R. Discourse referents are placed on the d-axis according to their relative distance from the speaker, which rests on the foreground/background perspective. The t-axis represents time as a bidirectional construct conceptualised in relation to the speaker's point of view. The present is close to the speaker, while the past and future are remote from the speaker, and point to opposite directions. The $\mathrm{m}$-axis models epistemic distance from the speaker and points only in direction away from the deictic centre, ranging from the epistemic judgement of certainty to counterfactuality. Discourse entities that are conceived of as having a higher level of certainty are spatially more proximal to the speaker and, conversely, those with lower level of certainty are conceptualised as distal. What on the m-axis is conceptualised as remote is also uncertain. The m-axis thus encodes the speaker's commitment to the truth or factuality of an assertion that a state of affairs will occur or commitment to the truth of a proposition.

By postulating that for speakers what is close corresponds to what is most real, and what is maximally distal corresponds to what is counterfactual, negated or unreal, DST establishes a correlation between spatial distance and epistemic distance that is extremely valuable in assessing the function that Russian and Chinese distal deictics hold in conditional contexts, where they not only have their primary function of marking spatial or temporal reference, but are also involved in epistemic meaning.

DST maintains that types of conditional sentences yield mental representations that can be arranged scalarly on the modality axis in terms of their epistemic distance from the speaker. They are conceived as expressing degrees of irreality, ranging from not-quite-certain to counter to fact. Counterfactual conditionals occupy the furthest position on the axis, the furthest 'possible world' relative to the position of the speaker (Chilton 2014: 162). The temporal axis maps onto the modality axis, that is temporal distance correlates with epistemic distance. Counterfactuality represents thus the strongest instance of both temporal and epistemic distance. In what seems to be a natural cognitive association, the different degrees of past-ness in conditional constructions are interpreted as degrees of epistemic certainty. This is evident in the coding of counterfactuality in English, as well as in Russian, Polish and other Indo-European languages, through the use of past forms together with a conditional 
marker. The conditional conjunction if is a modalising cognitive operator that signals that any expression in its scope is at some distance on the modality axis. If also transforms the Speaker's deictic space into a new set of axes (a new coordinate system), i.e. an irrealis space that is inconsistent with the initial space that the speaker considers as reality.

The occurrence of distal deictics in constructions involving epistemic uncertainty can, thus, be explained as a metaphorical extension from the basic meanings of remoteness in space and time to remoteness in certainty. It is a direct conceptual transfer from space/time to modality, retaining deictic relations. The deictic semantics of Russian and Chinese distal demonstratives fits smoothly into a cognitive interpretation.

Every analysis carried out on specific corpora, which are by definition finite bodies of data, is obviously conditioned by their characteristics, and should ideally be pursued further by investigating other corpora, including those containing texts that do not follow strict writing constraints (for example, e-mail messages, posts on social network sites like Facebook, VKontakte, Odnoklassniki, Live Journal, Linkedin, Twitter and Instagram, messages on the WhatsApp, Telegram, Weibo and WeChat platforms etc.), in which the use of conditional connectives can also be traced in detail and statistical evidence.

\section{References}

Berger, T. (1991). Überlegungen zur Deixis im Russischen. In K. Hartenstein, \& H. Jachnow (Eds.), Slavistische Linguistik 1990. Referate des XVI. Konstanzer slavistischen Arbeitstreffens, Bochum/Löllinghausen, 19.-21.9.1990 (pp. 9-35). München: Sagner.

Boye, K. (2012). Epistemic Meaning: A Cross-Linguistic and Functional-Cognitive Study. Berlin: Mouton de Gruyter.

Bühler, K. (1990). [1934]. Theory of Language: The Representational Function of Language. Trans. by Donald Fraser Goodwin. Amsterdam/Philadelphia: John Benjamins.

Chilton, P. (2005). Vectors, viewpoint and viewpoint shift: toward a Discourse Space Theory. Annual Review of Cognitive Linguistics, 3, 78-116. https://doi.org/10.1075/arcl.3.06chi

Chilton, P. (2010). From mind to grammar: Coordinate systems, prepositions, constructions. In V. Evans, \& P. Chilton (Eds.), Language, Cognition and Space: The State of the Art and New Directions (pp. 331-370). London: Equinox Publishing.

Chilton, P. (2014). Language, space and mind. The conceptual geometry of linguistic meaning. Cambridge: Cambridge University Press.

Dancygier, B. (1999). Conditionals and Prediction. Time, Knowledge, and Causation in Conditional Constructions. Cambridge: Cambridge University Press.

De Haan, F. (2002). Strong modality and negation in Russian. In R. Reppen, S. M. Fitzmaurice, \& D. Biber (Eds.), Using Corpora to Explore Linguistic Variation (pp. 91-110). Amsterdam/Philadelphia: John Benjamins. 


\section{Macrothink}

International Journal of Linguistics

ISSN 1948-5425 2020, Vol. 12, No. 2

Diessel, H. (1999). Demonstratives: form, function, and grammaticalization. Amsterdam/Philadelphia: John Benjamins.

Diessel, H. (2019a). The grammar network, how linguistic structure is shaped by language use. Cambridge: Cambridge University Press.

Diessel, H. (2019b). Deixis and Demonstratives. In C. Maienborn, K. Heusinger, \& P. Portner (Eds.), Semantics - Interfaces (pp. 463-493). Berlin/Boston: De Gruyter Mouton.

Fauconnier, G. (1994). Mental spaces: aspects of meaning construction in natural language. Cambridge: Cambridge University Press.

Fillmore, C. J. (1997). Lectures on Deixis. Stanford: CSLI publications.

Fleischman, S. (1989). Temporal distance: a basic linguistic metaphor. Studies in Language, 13(1), 1-50. https://doi.org/10.1075/sl.13.1.02fle

Frawley, W. (1992). Linguistic semantics. Hillsdale, NJ: Lawrence Erlbaum.

Gärdenfors, P. (2000). Conceptual spaces: the geometry of thought. Cambridge, MA: MIT Press.

Grenoble, L. (1998). Deixis and information packaging in Russian discourse. Amsterdam/Philadelphia: John Benjamins.

Grishina, E. (2009). Multimodal Russian Corpus (MURCO): General Structure and User Interface. In J. Levická, \& R. Garabík (Eds.), NLP, Corpus Linguistics, Corpus Based Grammar Research, Fifth International Conference (pp.119-131). Brno: Tribune.

Gurevich, O. (2010). Conditional Constructions in English and Russian. In H. C. Boas (Ed.), Contrastive Studies in Construction Grammar (pp. 87-102). Amsterdam/Philadelphia: John Benjamins.

Hansen, B. (2010). Mood in Russian. In B. Rothstein, \& R. Thieroff (Eds.), Mood in the Languages of Europe (pp. 325-341). Amsterdam/Philadelphia: John Benjamins.

Hsieh, C-L. (2005). Modal verbs and modal adverbs in Chinese: An investigation into the semantic source. UST Working Papers in Linguistics, 1, 31-58.

Huang, C-R., \& Shi, D. (2016). A reference grammar of Chinese. Cambridge: Cambridge University Press.

Jungbluth, K., \& Da Milano, F. (2016). Introduction. In K. Jungbluth, \& F. Da Milano (Eds.), Manual of Deixis in Romance Languages (pp. 1-17). Berlin/Boston: De Gruyter.

Kragh, K. J., \& Lindschouw, L. (2013). Deixis and pronouns in Romance languages. Amsterdam/Philadelphia: John Benjamins.

Lander, E., \& Haegeman, L. (2018). The Nanosyntax of Spatial Deixis. Studia Linguistica, 72(2), 362-427. https://doi.org/10.1111/stul.12061

Levinson, S. C. (1983). Pragmatics. Cambridge: Cambridge University Press. 
Levinson, S. C. (2018). Demonstratives: Patterns in Diversity. In S. C. Levinson, S. Cutfield, M. J. Dunn, N. J. Enfield, \& S. Meira (Eds.), Demonstratives in Cross-Linguistic Perspective (pp. 1-42). Cambridge: Cambridge University Press.

Li, E. S-H. (2007). A systemic functional grammar of Chinese. London: Continuum.

Lyons, J. (1977). Semantics. Cambridge: Cambridge University Press.

Meisterernst, B. (2016). The expression of epistemic modality in classical and Han period Chinese. In B. Meisterernst (Ed.), New aspects of classical Chinese grammar (pp. 105-130). Harraossowitz: Asien und Afrikastudien der Humboldt Universität.

Narrog, H. (2005). On defining modality again. Language Sciences, 27(2), 165-192. https://doi.org/10.1016/j.langsci.2003.11.007

Nuyts, J. (2016). Analyses of the modal meanings. In J. Nuyts, \& J. Van Der Auwera (Eds.), The Oxford Handbook of Modality and Mood (pp. 31-49). Oxford: Oxford University Press.

Padučeva, E. (2016). Modal'nost'. In V. Plungjan, E. Dobrušina, E. Rachilina, \& N. Stojnova (Eds.), Materialy k korpusnoj grammatike russkogo jazyka, Čast' 1: Glagol (pp. 19-94). Cankt-Peterburg: Nestor-Istorija.

Palmer, F. (2001). Mood and Modality. Cambridge: Cambridge University Press.

Palmer, F. (2014). Modality and the English Modals (2nd ed.). New York: Routledge.

Pekelis, O. (2016). Correlative markers, contrastiveness and grammaticalization: A comparative study of conditional correlatives in Russian and Italian. Italian Journal of Linguistics, 28(2), 143-180.

Pietrandrea, P. (2005). Epistemic Modality: Functional properties and the Italian system. Amsterdam/Philadelphia: John Benjamins.

Plungian, V. (2005). Irrealis and Modality in Russian and in Typological Perspective. In B. Hansen, \& P. Karlík (Eds.), Modality in Slavonic languages: New perspectives (pp. 135-147). München: Otto Sagner.

Plungian, V. (2010). Types of Verbal Evidentiality Marking: an Overview. In G. Diewald, \& E. Smirnova (Eds.), Linguistic Realization of Evidentiality in European Languages (pp. 15-58). Berlin/New York: De Gruyter Mouton.

Podlesskaya, V. (1997). Syntax and Semantics of Resumption: Some Evidence from Russian Conditional Conjuncts. Russian Linguistics, 21(2), 25-55.

Preobraženskaja, M. (1983). Korreljaty. In V. Borkovskij (Ed.), Struktura predloženija v istorii vostočnoslavjanskich jazykov (pp. 213-236). Moskva: Nauka.

Sonnenhauser, B., \& Meermann, A. (2015). Distance in language: grounding a metaphor. Cambridge: Cambridge Scholars Publishing. 
Spencer, A., \& Luis, A. R. (2012). Clitics: An introduction. Cambridge: Cambridge University Press.

Sun, C. (2006). Chinese. A Linguistic introduction. Cambridge: Cambridge University Press.

Švedova, N. (1980). Russkaja grammatika. Moskva: Nauka 1980.

Wang, C-H. (2015). Tiáojiànjù zhōng de "na/name". ["Na/name" in conditional sentences]. Chinese Language Learning, 2, 41-48.

Wang, L. (1987a). Zhongguo Xiandai Yufa II [A Grammar of Modern Chinese II] [1943]. Taizhong: Landeng Wenhua Shiye Gongsi.

Wang. L. (1987b). Zhongguo Yufa Lilun II [Theory of Chinese Grammar II] [1943]. Taizhong: Landeng Wenhua Shiye Gongsi.

$\mathrm{Wu}, \mathrm{Y}$. (2004). Spatial demonstratives in English and Chinese. Amsterdam/Philadelphia: John Benjamins.

Xiong, J., \& Meisterernst, B. (2019). The Syntax and the Semantics of the Deontic Modals yīng and dāng in Early Buddhist Texts. In B. Meisterernst (Ed.), New Perspectives on Aspect and Modality in Chinese Historical Linguistics (pp. 191-220). Singapore: Peking University Press; Springer.

$\mathrm{Xu}$, J. (2015). Corpus-based Chinese studies. A historical review from the 1920 s to the present. Chinese Language and Discourse, 6(2), 218-244 https://doi.org/10.1075/cld.6.2.06xu Zeman, S. (2015). The elementary particles of distance in space, time, grammar, and discourse. In B. Sonnenhauser, \& A. Meermann (Eds.), Distance in language: grounding a metaphor (pp.7-36). Cambridge: Cambridge Scholars Publishing.

\section{Notes}

Note 1. Hsieh (2005) questions the adequateness of these categories for the analysis of modal verbs and adverbs in Chinese, suggesting a distinction of four categories, deontic, epistemic, dynamic and evaluative.

Note 2. In this study, the distance-related terms 'proximal' and 'distal' were used as descriptive labels. However, we acknowledge the fact that recently there has been extensive debate on what has been called the 'spatial bias' in the description of demonstrative systems, that is the "presumption that spatial distinctions, usually in terms of distance from the speaker, form the primary semantic axis ofcontrast between demonstrative items". See Levinson (2018: 7).

Note 3. Following Diessel (1999: 4), we use the term 'adnominal' for demonstratives that combine with a noun in a noun phrase, and 'pronominal' for demonstratives that occur autonomously in the argument position of verbs and other predicates. Demonstrative adverbs are locational deictics which are primarily used as verb modifiers, that is to indicate the location of the event or situation that is expressed by a cooccurring verb.

Note 4. In his first formulations, Chilton referred to the theory as Discourse Space Theory (Chilton, 2005; Chilton, 2010). 


\section{Macrothink}

International Journal of Linguistics

ISSN 1948-5425

2020, Vol. 12, No. 2

Note 5. We chose this corpus because it is one of the largest task-oriented human-human dialog corpus for which speech data is freely available. On the paucity of large spoken corpora of Chinese see Xu (2015).

Note 6. Russian conditional subordinator marker esli etymologically is a form of be plus the interrogative particle $l i$, therefore its meaning maybe understood transparently as "be it that".

Note 7. In Russian colloquial language it is frequent to repeat $Б Ы$ both after the conjunction and after the verb:

\section{Esli by ona chotela by}

If BY she wanted BY

'. . . if she wanted to ...'

See Spencer and Luis (2012: 217); Hansen (2010: 331).

Note 8. The abbreviations and glossing conventions used in this article follow the Leipzig Glossing Rules. TO, NÀ and other particles are given in uppercase and left in the original. The annotation conventions used in the MURCO corpus were preserved in the examples. Similarly, the annotations conventions used in the PolyU corpus were maintained, including the use of commas to mark pauses.

Note 9. Jiù is a function word which, when it is used in the second clause of a complex sentence, indicates that the first clause is a supposition, condition, cause or purpose (Wu 2004). Given that the first part of the sentence actually appears to imply an adverbial connective structure indicating time (a more overt statement of the implied meaning would be: yàoshi dāng língdăo pīpíng wǒ de shíhou, wǒ jiù fănjī dehuà, nà zăo hùnbuxiàqu le, where dāng... de shíhou means "when", "as"), jiù concurs with yaòshi in forming a conditional sentence. This is further marked by the use of conditional dehuà (Sun, 2006, p. 198).

Note 10. The informant is talking about an ancient Chinese stone brick wall, where individual bricks feature inscriptions bearing the name of the stonemason responsible for selecting and cutting the bricks.

Note 11. "Sure enough" is inserted at the end of the sentence to convey the mood given by the final modal particle $y a$.

Note 12. The Peking University Center for Chinese Linguistics corpus can be accessed freely at http://ccl.pku.edu.cn:8080/ccl_corpus/.

\section{Copyrights}

Copyright for this article is retained by the author(s), with first publication rights granted to the journal.

This is an open-access article distributed under the terms and conditions of the Creative Commons Attribution license (http://creativecommons.org/licenses/by/4.0/) 